Situs Jurnal : $\underline{\text { http://ejurnal.stiepancasetia.ac.id/index.php/jieb }}$

Jilid 5 Nomor 1 Maret 2019

Hal 060 - 076

\title{
ANALISIS SWOT DALAM IMPLENTASI PROMOTIONAL MIX DODOL PRODUKSI IBU MITA DI DESA KAPUH KANDANGAN
}

\section{Jumiati* dan Muhammad Humaidi}

Abstract: This study aims to analyze SWOT in the implantation of Mita's promotional Mix Dodol Production in Kapuh Kandangan Village. The variables used in this study are promotion and SWOT strategies. The population and samples in this study were 9 leaders and employees of Dodol Production Mita Kandangan Production. The technique of collecting data uses the method of observation, interviews, documentation, and literature. Data analysis techniques in this study are SWOT analysis (S) Strengths, (W) Weakness, (O) Opportunities, and (T) Threats. EFAS (External Strategic Factor Analysis Summary) and IFAS (External Factor Analysis Summary). This result that the promotion strategy to increase sales in the Production of Mother Mita Dodol in the Kapuh Kandangan Village is based on the EFAS Matrix analysis with a value of 2,843 indicating that the Ibu Mita Production Dodol in Kapuh Kandangan Village is able to anticipate opportunities that arise from the external environment and based on IFAS Matrix analysis obtained a value of 2,765, this indicates that the Production Mole of Mrs. Mita in Kapuh Kandangan Village has developed and can overcome weaknesses. Although externally able to anticipate external opportunities and threats, Ibu Mita's Production Dodol in Kapuh Kandangan Village needs internal improvement, so as to be able to use the power to take advantage of the opportunities.

Keywords: promotion strategy, SWOT, dodol, Kandangan Vilage

Abstrak: Penelitian ini bertujuan untuk menganlisis SWOT dalam implentasi promotional Mix Dodol Produksi Ibu Mita di Desa Kapuh Kandangan. Variabel yang digunakan dalam penelitian ini adalah strategi promosi dan SWOT. Populasi dan sampel dalam penelitian ini adalah pimpinan serta karyawan Dodol Produksi Ibu Mita Kandangan yang berjumlah 9 orang. Teknik pengumpulan data menggunakan metode observasi, wawancara, dokumentasi, dan studi pustaka. Teknik analisis data dalam penelitian ini adalah analisis SWOT (S) Strengths, (W) Weakness, (O) Opportunities, and (T) Threats. EFAS (Eksternal Strategic Factor Analysis Summary) dan IFAS (Eksternal Factor Analysis Summary). Hasil ini bahwa strategi promosi untuk meningkatkan penjualan pada Dodol Produksi Ibu Mita Di Desa Kapuh Kandangan adalah berdasarkan analisis Matriks EFAS diperoleh nilai sebesar 2,843 hal tersebut menunjukkan bahwa Dodol Produksi Ibu Mita di Desa Kapuh Kandangan mampu mengantisipasi peluang yang muncul dari lingkungan eksternal dan mengantisipasi datangnya ancaman dan berdasarkan analisis Matriks IFAS diperoleh nilai sebesar 2,765 hal tersebut menunjukkan bahwa Dodol Produksi Ibu Mita di Desa Kapuh Kandangan sudah berkembang dan dapat mengatasi kelemahan. Walaupun secara eksternal mampu mengantisipasi peluang dan ancaman eksternal, Dodol Produksi Ibu Mita di Desa Kapuh Kandangan perlu pembenahan secara internal, sehingga mampu menggunakan kekuatan yang dimiliki untuk memanfaatkan kesempatan yang ada.

Kata kunci : Strategi promosi, SWOT, dodol, Desa Kandangan

* Fakultas Ekonomi Universitas Achmad Yani Banjarmasin 


\section{Latar Belakang}

Pembentukan perniagaan nasional dan industri untuk meningkatkan efisiensi, daya saing menuju kemandirian dan barang yang makin bermutu. Pemerintah sekarang ini berusaha memberikan dukungan kepada perkembangan industri dengan misi agar memperluas kesempatan kerja dengan pertumbuhan ekonomi daerah untuk bersaing di era perdagangan bebas.

Perkembangan industri yang meningkat menyebabkan persaingan antara industri-industri rumah tangga semakin ketat, produk yang ada dipasaran bisa memiliki keseragaman produk antara produk lainya, untuk menghadapi kompetisi saat ini merupakan upaya yang dilakukan yaitu dengan mengorganisasikan strategi pemasaran efektif.

Pemasaran suatu bagian yang penting dengan pasar, karena pasar saat ini merupakan pasar pembeli, dimana negoisasi jual dan beli berdasarkan keputusan pembeli, sehingga perilaku konsumen dapat mempengaruhi pasar dan barang yang ditawarkan perusahaan hanya bisa menuruti kemauan konsumen dan bagaimana suatu perusahaan mengungguli perusahaan pesaing yang membuat barang serupa.

Fungsi dari pemasaran pada kenyataannya merupakan proses aktivitas rumit dari proses produksi sampai supaya barang sampai ke pembeli yang dapat memberikan keuntungan pada perusahaan atau balik modal. Assauri $(2017$ : 198) unsur variabel strategi pemasaran ada empat yaitu produk, harga, penyaluran/ distribusi, dan promosi.

Assauri (2017 : 265) Gabungan dari peralatan promosi, yang disebut acuan/bauran promosi (promotional mix), yaitu Advertensi, Penjualan langsung, Publisitas, Promosi penjualan.

Strategi promosi berarti menggambarkan perpaduan antara variabel yang digunakan oleh pemasar dengan cara megoptimalkan anggaran untuk membantu meningkatkan penjualan perusahaan.

Assauri (2017 : 271) Promosi adalah untuk memberitahukan kepada langganan dan calon pembeli yang potensial, tentang produk baru dan keuntungan yang didapat bila memakai produk baru tersebut.

Dodol Produksi Ibu Mita Kandangan merupakan industri kecil berupa pembuatan dodol yang terletak di Desa Kapuh, Kecamatan Simpur. Produsen olahan Dodol Produksi Ibu Mita yang memiliki 6 karyawan, yang setiap harinya bisa menghasilkan $180 \mathrm{~kg}$ dodol.

Dodol Produksi Ibu Mita yang mempunyai varian rasa dodol diantaranya: kacang, durian, pandan, stroberi, wajik, dan original. Produksi dodol ini cukup berkembang dan dapat memberikan penghasilan masyarakat yang bekerja di industri tersebut.

Pemasaran Dodol Produksi Ibu Mita Kandangan saat ini sudah dijual ke berbagai tempat di Kalsel, Kaltim dan Kalteng. Di kota Kandangan banyak industri yang bergerak di bidang yang sama seperti Dodol Mama Alfi (Hj. Hamdanah), Dodol Ibu Norjannah dan usaha dodol lainnya.

Peranan promosi di sektor pemasaran produk dapat mempermudah penjualan dan mendapatkan konsumen atau pemakai. Dengan adanya strategi pemasaran, sehingga pemasaran oleh pihak industri dapat bersaing dengan industri-industri lain.

Strategi promosi yang ditetapkan industri ini masih belum efektif karena disebabkan oleh beberapa faktor, Dodol Produksi Ibu Mita Kandangan menjual produknya secara tatap muka (Personal Selling) ke toko-toko disekitar kota Kandangan dan kota lain, sedangkan strategi promosi yang lain seperti advertensi, yaitu dengan memasang papan reklame yang dapat ditemukan di sepanjang Jalan Trans-Kalimantan yakni di kota Rantau, Kandangan, Barabai, Tanjung hingga di perbatasan Kalsel dan Kaltim. Industri pesaing yang begerak di bidang yang sama juga dapat mempengaruhi dalam penjualan produk dodol. 
Berkaitan dengan pentingnya strategi promosi, perlu diterapkan kepada industri olahan Dodol Produksi Ibu Mita.

Tabel 1. Penjualan Dodol Produksi Ibu Mita Kandangan Tahun 2017 Dalam kurun waktu 12 bulan

\begin{tabular}{cccccccc}
\hline \multirow{2}{*}{ No. } & Bulan & \multicolumn{3}{c}{ Bentuk isi 500 $\mathrm{g}$} & \multicolumn{3}{c}{ Bentuk isi 250 g } \\
\cline { 3 - 7 } & & $\begin{array}{c}\text { Target } \\
\text { Penjualan }\end{array}$ & $\begin{array}{c}\text { Realisasi } \\
\text { Penjualan }\end{array}$ & $\begin{array}{c}\text { Pencapaian } \\
(\%)\end{array}$ & $\begin{array}{c}\text { Target } \\
\text { Penjualan }\end{array}$ & $\begin{array}{c}\text { Realisasi } \\
\text { Penjualan }\end{array}$ & $\begin{array}{c}\text { Pencapaian } \\
(\%)\end{array}$ \\
\hline 1. & Januari & 5.400 & 4.052 & 75,03 & 10.800 & 8.211 & 76,02 \\
\hline 2. & Februari & 5.400 & 4.160 & 77,03 & 10.800 & 8.650 & 80,09 \\
\hline 3. & Maret & 5.400 & 7.153 & 76,90 & 10.800 & 8.641 & 80,00 \\
\hline 4. & April & 5.400 & 3.883 & 71,90 & 10.800 & 7.562 & 70,01 \\
\hline 5. & Mei & 5.400 & 4.120 & 76,29 & 10.800 & 8.644 & 80,03 \\
\hline 6. & Juni & 5.400 & 4.035 & 74,72 & 10.800 & 8.420 & 77,96 \\
\hline 7. & Juli & 5.400 & 3.940 & 72,96 & 10.800 & 8.642 & 80,01 \\
\hline 8. & Agustus & 5.400 & 3.621 & 67,05 & 10.800 & 7.130 & 66,01 \\
\hline 9. & September & 5.400 & 3.509 & 64,98 & 10.800 & 7.455 & 69,02 \\
\hline 10. & Oktober & 5.400 & 3.998 & 74,03 & 10.800 & 8.427 & 78,02 \\
\hline 11. & Nopember & 5.400 & 3.890 & 72,03 & 10.800 & 8.315 & 76,99 \\
\hline 12. & Desember & 5.400 & 3.995 & 73,98 & 10.800 & 8.643 & 80,02 \\
\hline
\end{tabular}

Berdasarkan dari tabel 1, penjualan produk dodol mengalami penurunan penjualan pada bulan Agustus dan September dibanding penjualan di bulan lainnya. Hal ini disebabkan oleh beberapa faktor, salah satunya strategi promosi yang diterapkan industri masih belum efektif karena Dodol Produksi Ibu Mita Kandangan hanya menjual produknya secara tatap muka (Personal Selling) ke toko-toko disekitar kota Kandangan dan kota lain. Sedangkan strategi promosi yang lain seperti advertensi, yaitu dengan memasang papan reklame yang dapat ditemukan di sepanjang Jalan Trans-Kalimantan. Industri pesaing yang begerak di bidang yang sama juga dapat mempengaruhi dalam penjualan produk dodol.

Diharapkan dengan adanya penerapan strategi promosi Dodol Produksi Ibu Mita Kandangan dapat melakukan pengembangan jaringan agen penjualan, mengikuti acara-acara, pameran dan promosi lewat media sosial. Penerapan strategi yang dilakukan industri hanya berdasarkan pengalaman pemilik industri, tanpa melihat potensi dan peluang yang dimiliki industri tersebut.

Salah satu upaya untuk memperbaiki penurunan penjualan produk dodol yaitu dengan membuat strategi promosi supaya lebih efektif, yaitu dengan menggunakan perhitungan SWOT (Strength, Weaknesses, Oportunities, and Threath). Analisis ini bertujuan untuk melihat (S) kekuatan, (W) kelemahan, (O) peluang dan (T) ancaman yang dihadapi oleh perusahaan.

Berdasarkan keterangan di atas maka diperoleh judul "Penerapan Strategi Promosi Untuk Meningkatkan Penjualan Pada Dodol Produksi Ibu Mita Di Desa Kapuh Kandangan".

Berdasarkan dari latar belakang dapat diidentifikasi beberapa masalah sebagai berikut: Penjualan Dodol Produksi Ibu Mita mengalami penurunan di bulan Agustus dan September.Promosi penjualan kurang efektif yang ditetapkan produsen Dodol Produksi Ibu Mita.Banyaknya industri pesaing di bidang yang serupa dalam penjualan produk dodol.Berdasarkan identifikasi tersebut maka dirumuskan suatu pertanyaan: "Bagaimana menganalisis SWOT untuk dapat melaksanakan bauran promosi yang efektif Pada Dodol Produksi Ibu Mita di Desa Kapuh Kandangan?”. 


\section{Kajian Literatur}

Pemasaran suatu bagian yang penting dengan pasar, karena pasar saat ini merupakan pasar pembeli, dimana negoisasi jual dan beli berdasarkan keputusan pembeli, sehingga perilaku konsumen dapat mempengaruhi pasar dan barang yang ditawarkan perusahaan hanya bisa menuruti kemauan konsumen dan bagaimana suatu perusahaan mengungguli perusahaan pesaing yang membuat barang serupa.

Fungsi dari pemasaran pada kenyataannya merupakan proses aktivitas rumit dari proses produksi sampai supaya barang sampai ke pembeli yang dapat memberikan keuntungan pada perusahaan atau balik modal. ahli:

Pengertian pemasaran dalam Daryanto (2013 : 83-84) menurut pendapat dari beberapa

1. Willian J. Stanton, pemasaran adalah gabungan dari aktivitas yang bermaksud untuk mempersiapkan, menentukan harga, mendistribusikan barang/jasa dan mempromosikannya.

2. Philip dan Duncan, pemasaran mencakup tahap-tahap untuk dapat memberikan produk nyata kepada pembeli.

3. American Marketing Association, pemasaran mencakup aktivitas perdangangan untuk ditujukan pada proses pengiriman barang/jasa dari pembuat ke konsumen.

Berdasarkan pengertian tersebut bahwa pemasaran berarti berbagai aktivitas industri sebagai penetapan harga, distribusi dan lainnya. Dalam hal ini kegunaan penjualan atau fungsi pemasaran sangat diperlukan karena menyangkut kesuksesan dan pertumbuhan perusahaan.

Daryanto (2013 : 1) pemasaran merupakan dari cara kemasyarakatan dimana perseorangan dan kelompok memperoleh keinginan dan keperluan mereka dengan membuat, mempromosikan dan bertukar sesuatu dan dapat menguntungkan satu sama lain.

Berdasarkan pernyataan beberapa ahli dapat disimpulkan pemasaran adalah aktivitas dari usaha yang dilaksanakan oleh perusahaan untuk merencanakan, memproduksi, menentukan harga dan menawarkan suatu manfaat kepada langganan dan calon pembeli potensial.

Assauri (2017 : 198) strategi pemasaran merupakan gabungan asas yang tepat, konsisten, dan bisa dilakukan sebuah organisasi untuk mencapai sasaran pasar dalam waktu jangka panjang di dalam suatu persaingan tertentu. Assauri (2017 : 198-199) strategi acuan pemasaran ada empat yaitu : strategi produk, strategi harga, strategi penyaluran/distribusi, dan strategi promosi.

1. Strategi Produk

Daryanto (2013 : 52) produk ialah semua objek/materi yang bisa dijualbelikan ke pasar agar dapat diperhatikan, dibeli dan digunakan/dikonsumsi. Tjiptono (2015:231) produk sesuatu (barang/jasa) yang ditawarkan pembuat untuk dilirik, diinginkan, dicari dan dibeli untuk melengkapi kebutuhan pasar. Assauri (2017 : 200) produk adalah menawarkan sesuatu kepada pasar untuk dilirik, dimiliki, dipakai dan dikonsumsi yang mencakup barang secara fisik/jasa.

Berdasarkan beberapa pendapat ahli dapat disimpulkan, produk berarti penjual menawarkan sesuatu untuk dilirik, diminta, dan dibeli konsumen untuk digunakan atau dikonsumsi, yang bertujuan mencapai sasaran pasar untuk mengatasi lawan sebuah perusahaan.

Strategi produk adalah unsur yang penting di dalam sebuah strategi penjualan lainnya. Strategi produk mencakup berbagai keputusan tentang acuan/bauran produk, merek dangang, kemasan produk, tingkat mutu/kualitas dari produk, dan pelayanan (services) yang diberikan. 


\section{a. Merek Dagang (Brand)}

Merek dagang adalah nama, tanda, dan istilah, yang memiliki tujuan untuk menemukan barang/jasa dari penjual agar tidak memiliki kesamaan dari produk lainnya.

b. Kemasan (Packaging)

Kemasan adalah pembungkus yang memiliki makna penting, karena kemasan bukan hanya untuk melindungi produk, tetapi dapat menyenangkan dan menarik pelanggan.

c. Kualitas (Mutu) Produk

Mutu produk adalah sesuatu yang harus diperhatikan oleh perusahaan, karena suatu kualitas berhubungan erat dengan masalah kepuasan konsumen dari tujuan sebuah aktivitas pemasaran yang dilakukan oleh perusahaan.

d. Pelayanan (Service)

Pelayanan merupakan kesuksesan dari pemasaran suatu produk yang dapat ditentukan oleh pelayanan dari perusahaan dalam memasarkan suatu produk.

\section{Strategi Harga}

Produsen dalam menetapkan harga dapat mempengaruhi dalam persaingan dan kemampuan produsen mempengaruhi pelanggan. Dalam menetapkan suatu harga yang harus diperhatikan unsur-unsur yang dapat mempengaruhinya, baik langsung atau tidak langsung. Unsur yang secara langsung, yaitu harga bahan baku, biaya pengolahan, biaya promosi, kebijakan pemerintah, dan unsur lainnya. Unsur yang tidak langsung, namun memiliki hubungan erat di dalam suatu penetapan harga, adalah produk serupa oleh produk pesaing.

Daryanto (2013 : 62) harga merupakan sejumlah nilai yang dibayar dengan uang yang dipertukarkan pembeli untuk membeli produk. Berdasarkan pengertian harga tersebut, harga adalah nilai suatu barang yang dapat ditukar dengan uang.

\section{Strategi penyaluran/Distribusi}

Distribusi merupakan aktivitas pembagian produk sampai ke konsumen. Kebijakan pembagian adalah suatu strategi penjualan terstruktur. Daryanto (2013 : 100) distribusi merupakan saluran yang digunakan perusahaan untuk membagikan barang hasil produksi kepada si pemakai atau konsumen, baik berpindahnya hak (penguasaan) hingga pengalihan hak milik.

\section{Strategi Promosi}

Strategi promosi merupakan aktivitas perusahaan untuk memberitahukan ke konsumen tentang suatu produknya dan apa saja manfaat bila membeli produk tersebut. Assauri (2017 : 271) Promosi adalah untuk memberitahukan kepada langganan dan calon langganan yang potensial, tentang adanya produk baru dan keuntungan apa saja yang didapat bila memakai produk baru tersebut. Daryanto (2013 : 104) promosi bertujuan memberitahukan dan mengarahkan kelompok atau individu untuk membuat terjadinya transaksi antara pembeli dan penjual.

Assauri (2017 : 268) Kegiatan promosi yang dilakukan suatu perusahaan menggunakan acuan/bauran promosi (Promotional Mix) yang terdiri dari:

1. Advertensi, merupakan bentuk penyajian dan gagasan, barang/jasa yang dibiayai oleh sponsor yang bukan pribadi. Media yang digunakan adalah radio, TV, papan iklan, majalah, dan surat kabar.

2. Penjualan pribadi, menyajikan secara langsung di dalam percakapan dengan individu atau kelompok sehingga dapat terwujudnya penjualan. 
3. Promosi penjualan, sesuatu aktivitas yang dapat mengarahkan pelanggan untuk membeli sebuah produk dengan melakukan pameran, demonstrasi dan semua usaha secara tidak teratur.

4. Publisitas (Publicity), usaha meningkatkan permintaan produk secara tidak pribadi, bersifat umum tentang produk di media cetak/tidak, maupun dari hasil suatu wawancara/keterangan yang diberitahukan lewat media.

Tjiptono (2015 : 399-400) Deskripsi dan contoh alat bauran promosi pemasaran terpadu terdiri dari:

1. Periklanan, presentasi dan promosi barang/jasa yang biayanya ditanggung sponsor. Media yang digunakan yaitu media cetak, media elektronik, buklet, kemasan brosur, leaflet poster, billboards, simbol, pajangan, dan logo.

2. Promosi penjualan, berbagai macam insentif dengan tempo pendek yang bertujuan untuk memicu pembelian produk/jasa. Alat yang digunakan yaitu kontes, undian, produk contoh, demonstrasi, pameran, kupon, pembayaran bunga rendah, dan tukar tambah.

3. Public relations, Berbagai macam rancangan promosi dan melindungi nama baik perusahaan/produknya. Pidato, donasi, seminar, laporan tahunan, sponsorships, publikasi, acara-acara, lobbiying, dan majalah perusahaan.

4. Personal selling, interaksi secara langsung dengan individu atau kelompok calon konsumen untuk mendapatkan pesanan dan menanggapi pertanyaan. Presentasi, insentif, pertemuan penjualan, pameran, dan produk contoh.

5. Direct \& online marketing, penggunaan surat telepon, fax, e-mail atau Internet untuk berkomunikasi secara langsung kepada pelanggan atau untuk mendapatkan respon langsung dari pelanggan dan calon pelanggan spesifik. Media yang digunakan yaitu katalog, surat, telemarketing, elektronic shopping, TV shoping, fax mail, e-mail, voice mail, dan lain-lain.

Rangkuti (2016 : 19) Analisis SWOT ialah mengenal berbagai unsur secara tersusun untuk merumuskan rancangan perusahaan. Analisis ini berdasarkan pada pemikiran yang bisa meningkatkan (S) kekuatan dan (O) peluang, yang dapat meminimalkan (W) kelemahan dan (T) ancaman. Pengambilan keputusan siasat senantiasa berkaitan dengan memperluas misi, rencana, tujuan, dan peraturan perusahaan. Susanto dalam Edison dkk. (2016 : 17) Analisis SWOT adalah alat yang penting untuk perumusan strategi. Asumsi utama yang pokok adalah bahwa perusahaan harus menyelaraskan kegiatan didalamnya dengan realitas eksternal untuk dapat mencapai target yang ditentukan.

1. Tahap Perencanaan Strategi

Langkah pertama untuk suatu penelitian yaitu dengan mengatur strategi. Tahap yang digunakan yaitu: menganalisis visi dan misi, serta tujuan organisasi, selanjutnya menganalisis unsur di dalam dan diluar perusahaan. Langkah selanjutnya membuat matriks pada masing-masing faktor. Selanjutnya, mengolah data yang berkaitan pada matriks yang dibuat. Selanjutnya akan didapat strategi yang dapat diterapkan pada organisasi yang diteliti.

\section{Matriks Faktor Strategi Eksternal}

Berikut ini langkah-langkah dalam menentukan Faktor Strategi Eksternal:

a. Susunlah dalam (kolom 1), (5 - 10 faktor peluang dan ancaman).

b. Berikan bobot tiap-tiap faktor (di kolom 2 ) dari sangat penting $(1,0)$ sampai tidak penting $(0,0)$.

c. Hitung rating di dalam (kolom 3) pada tiap-tiap faktor dan memberikan skala dari outstanding 4 sampai poor 1, sesuai pengaruh pada faktor terhadap keadaan perusahaan 
tersebut. Nilai rating pada faktor peluang memiliki sifat positif (semakin besar peluang diberi nilai rating +4 , apabila peluangnya kecil, maka diberi nilai rating +1 ). Nilai rating terhadap faktor ancaman ialah kebalikannya. Apabila, ancamannya sangat besar, maka ratingnya adalah 1 . Sebaliknya, jika ancamannya sedikit maka nilai ratingnya 4.

d. Kalikan pada bobot di (kolom 2) dengan rating (kolom 3) untuk mendapatkan faktor pembobotan di (kolom 4). Hasilnya adalah angka pembobotan untuk tiap faktor nilainya berbeda-beda mulai dari outstanding 4,0 sampai poor 1,0.

e. Memberikan komentar/catatan pada (kolom 5) mengapa faktor-faktor tersebut dipilih.

f. Menjumlahkan angka pembobotan (di kolom 4) untuk mendapatkan (total) angka pembobotan perusahaan yang berkaitan.

Tabel 2. Contoh Perhitungan EFAS

\begin{tabular}{|c|c|c|c|c|}
\hline $\begin{array}{c}\text { FAKTOR-FAKTOR } \\
\text { STRATEGI EKSTERNAL }\end{array}$ & BOBOT & RATING & $\begin{array}{l}\text { BOBOT X } \\
\text { RATING }\end{array}$ & KOMENTAR \\
\hline \multicolumn{5}{|l|}{ PELUANG: } \\
\hline - Integrasi ekonomi Eropa & 0,20 & 4 & 0,80 & Akuisisi \\
\hline - Perubahan struktur demografi & 0,15 & 4 & 0,60 & Kualitas \\
\hline - Pembangunan ekonomi di Asia & 0,15 & 4 & 0,60 & Maytag \\
\hline - Terbukanya Eropa Timur & 0,20 & 3 & 0,60 & Keberadaan \\
\hline - Kecenderungan superstores & 0,10 & 3 & 0,30 & Lemah \\
\hline \multicolumn{5}{|l|}{ ANCAMAN: } \\
\hline $\begin{array}{l}\text { - Meningkatnya peraturan } \\
\text { pemerintah }\end{array}$ & 0,02 & 2 & 0,04 & $\begin{array}{l}\text { Perlu } \\
\text { hati-hati }\end{array}$ \\
\hline $\begin{array}{ll}\text { - } & \text { Meningkatnya } \\
\text { - } & \text { Persaingan } \\
\end{array}$ & 0,05 & 2 & 0,10 & $\begin{array}{l}\text { Perlu } \\
\text { hati-hati }\end{array}$ \\
\hline $\begin{array}{l}\text { - Whirlpool dan Electrolux menjadi } \\
\text { global }\end{array}$ & 0,05 & 2 & 0,05 & $\begin{array}{l}\text { Tantangan } \\
\text { baru }\end{array}$ \\
\hline - Munculnya teknologi baru & 0,05 & 1 & 0,05 & $?$ \\
\hline - $\quad$ Perusahaan Jepang & 0,03 & 1 & 0,03 & diperhatikan \\
\hline TOTAL & 1,00 & & 3,17 & \\
\hline
\end{tabular}

Sumber: Rangkuti (2016:26)

\section{Matriks Faktor Strategi Internal}

Berikut ini langkah-langkah dalam menentukan Faktor Strategi Eksternal:

a. (kolom 1) tentukan faktor-faktor kekuatan dan kelemahan perusahaan.

b. Berikan bobot tiap-tiap faktor (di kolom 2 ) dari sangat penting $(1,0)$ sampai tidak penting $(0,0)$. Jumlah bobot tidak boleh lebih dari angka total 1,00.

c. Hitunglah rating pada (kolom 3) pada tiap-tiap faktor dan memberikan skala dari outstanding 4 sampai poor 1, sesuai pengaruh pada faktor terhadap keadaan perusahaan tersebut. Nilai rating pada faktor kekuatan memiliki sifat positif diberi nilai rating +1 , sampai +4 (sangat baik). Pemberian (nilai 1) jika kelemahan pada perusahaan besar sekali daripada rata-rata industri, sedangkan (nilai 4) diberikan jika kelemahan perusahaaan di bawah dari rata-rata industri.

d. Kalikan bobot (kolom 2) dengan rating (kolom 3) untuk mendapatkan faktor pembobotan di (kolom 4). Hasilnya adalah angka pembobotan untuk tiap faktor nilainya berbeda-beda mulai dari outstanding 4,0 sampai poor 1,0.

e. Memberikan komentar/catatan pada (kolom 5) mengapa faktor-faktor tersebut dipilih. 
f. Menjumlahkan angka pembobotan (di kolom 4) untuk mendapatkan (total) angka pembobotan perusahaan yang berkaitan.

Tabel 3. Contoh Perhitungan IFAS

\begin{tabular}{|c|c|c|c|c|}
\hline $\begin{array}{c}\text { FAKTOR-FAKTOR } \\
\text { STRATEGI INTERNAL }\end{array}$ & BOBOT & RATING & $\begin{array}{l}\text { BOBOT X } \\
\text { RATING }\end{array}$ & KOMENTAR \\
\hline \multicolumn{5}{|l|}{ KEKUATAN: } \\
\hline - Budaya kualitas Maytag & 0,15 & 4 & 0,60 & $\begin{array}{l}\text { Kualitas } \\
\text { kunci sukses }\end{array}$ \\
\hline - $\quad$ Pengalaman Top Manajer & 0,15 & 4 & 0,60 & Mengetahui produk \\
\hline - Integrasi vertical & 0,10 & 4 & 0,40 & Hubungan baik \\
\hline $\begin{array}{ll}\text { - } & \text { Hubungan yang baik } \\
\text { dengan SDM }\end{array}$ & 0,05 & 3 & 0,15 & $\begin{array}{l}\text { Baik tapi cenderung } \\
\text { turun }\end{array}$ \\
\hline $\begin{array}{ll}\text { - Memiliki orientas } \\
\text { internasional }\end{array}$ & 0,15 & 3 & 0,45 & $\begin{array}{l}\text { Memiliki reputasi baik } \\
\text { di pembersih }\end{array}$ \\
\hline \multicolumn{5}{|l|}{ KELEMAHAN: } \\
\hline - $\quad$ Proses produksi (R\&D) & 0,05 & 2 & 0,10 & $\begin{array}{l}\text { Lambat untuk produk } \\
\text { baru }\end{array}$ \\
\hline - $\quad$ Saluran distribusi & 0,05 & 2 & 0,10 & Ancaman Superstore \\
\hline $\begin{array}{l}\text { - Dukungan kondisi } \\
\text { keuangan kurang begitu } \\
\text { baik }\end{array}$ & 0,15 & 1 & 0,30 & Tingginya utang \\
\hline $\begin{array}{ll}\text { - } & \text { Posisi global sangat } \\
\text { kurang }\end{array}$ & 0,10 & 1 & 0,10 & Lemah diluar UK \\
\hline - Fasilitas manufaktur & 0,05 & 1 & 0,05 & $\begin{array}{l}\text { Perlu } \\
\text { investasi sekarang }\end{array}$ \\
\hline TOTAL & 1,00 & & 2,85 & \\
\hline
\end{tabular}

Sumber: Rangkuti $(2016: 27)$

Berdasarkan teori-teori yang telah dikemukakan, dapat dibuat kerangka berpikir dari penelitian ini yaitu seperti Gambar 1 .

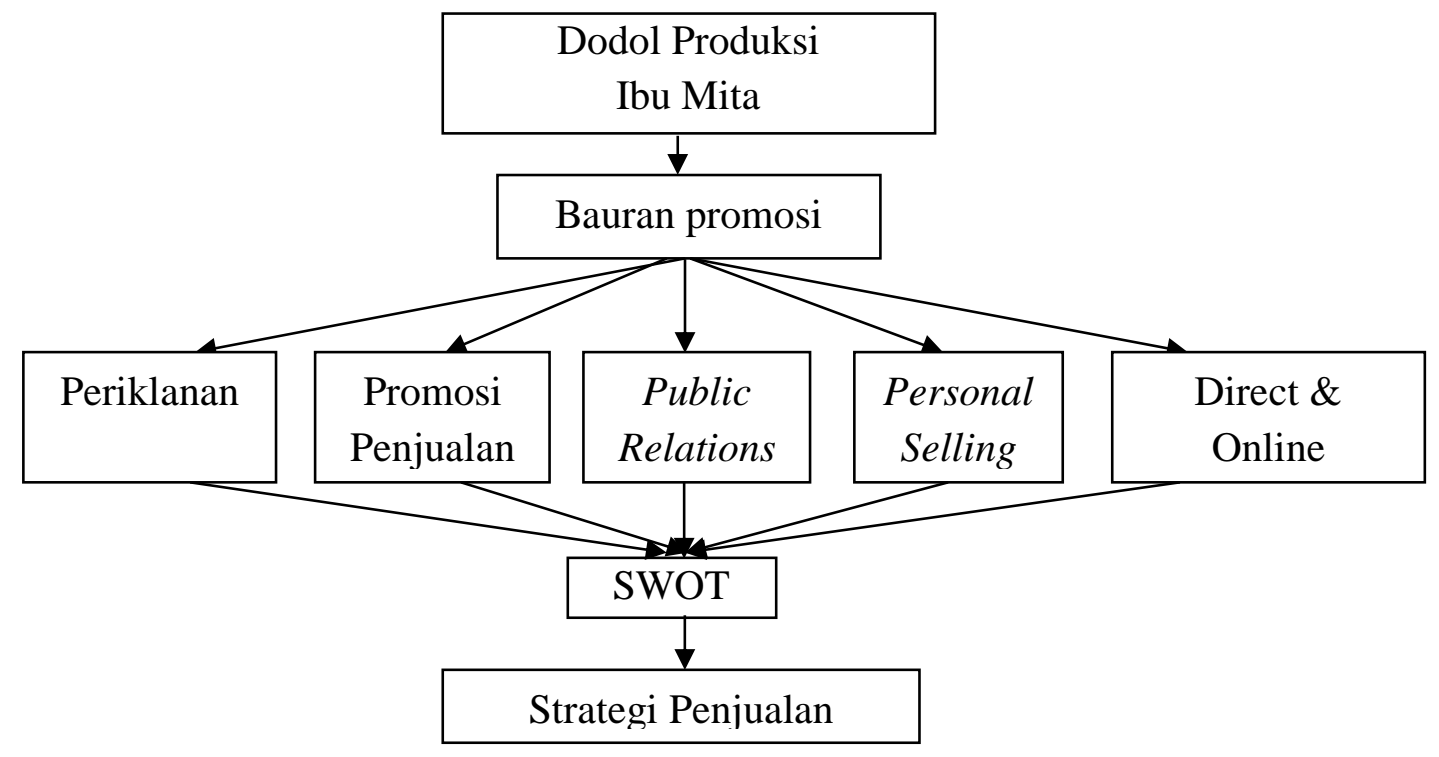

\section{Gambar 1. Kerangka Berfikir Penelitian}




\section{Metode Penelitian}

Pelaksanaan penelitian ini bertempat di industri rumah tangga pembuatan dodol produksi Ibu Mita yang terletak di desa Kapuh, Kecamatan Simpur, kota Kandangan. Penelitian dilaksanakan di bulan Oktober s/d Desember 2017.

Sugiyono (2017 : 2) Variabel penelitian merupakan segala hal yang ditetapkan peneliti dengan mempelajari bentuk apa saja, sehingga didapat keterangan mengenai hal tersebut dan ditarik kesimpulannya. Penelitian ini memiliki dua variabel yaitu Promosi dan Pemasaran. Promosi bertujuan memberitahukan dan mengarahkan kelompok atau individu untuk membuat terjadinya proses jual beli antara pembeli dan penjual.

Indikator dari promosi yang diterapkan adalah bentuk-bentuk promosi: Periklanan, Promosi Penjualan, Publisitas, Pesonal Selling, Direct \& Online Marketing.

1. Periklanan: Presentasi dan promosi, barang/jasa yang dibayarkan oleh sponsor.

2. Promosi Penjualan: Berbagai macam insentif dengan tempo pendek yang bermaksud untuk memicu pembelian suatu produk/jasa.

3. Public Relations: Berbagai macam rancangan promosi dan melindungi nama baik perusahaan/produknya.

4. Personal Selling: Interaksi langsung kepada individu dan kelompok calon konsumen untuk mendapatkan pesanan dan menanggapi pertanyaan.

5. Direct \& Online Marketing: Penggunaan surat, telepon, fax, e-mail atau Internet untuk berkomunikasi secara langsung kepada pelanggan atau untuk mendapatkan respon langsung dari konsumen atau calon pembeli.

Sumber data yang digunakan dalam penelitian ini adalah data primer dan data sekunder, yaitu:

1. Data Primer

Suryabrata (2014 : 39) Data primer ialah data langsung yang dikumpulkan peneliti (atau petugas-petugasnya) dari sumber awal. Data primer berupa opini secara perseorangan atau lebih, hasil penelitian terhadap suatu kejadian atau kegiatan.

2. Data Sekunder

Suryabrata (2014 : 39) Data sekunder ialah data yang biasa tersusun dalam suatu bentuk dokumen-dokumen. Data sekunder berupa catatan, bukti, dan laporan masa lalu atau arsip. Data sekunder penelitian adalah: data jumlah penjualan.

Data suatu hal penting dalam suatu penelitian, berguna untuk mendapatkan laporan yang sesuai pada permasalahan yang dibahas dalam penelitian ini, cara mendapatkan data sebagai berikut:

1. Wawancara

Wawancara adalah dengan bertanya secara langsung kepada subjek penelitian.

2. Observasi

Observasi ialah dengan cara pengamatan langsung pada objek penelitian.

3. Studi Pustaka

Studi pustaka yaitu metode pengumpulan laporan yang di dapat melalui buku atau bahan acuan yang memiliki kaitan terhadap materi penelitian.

Penelitian ini menggunakan (analisis deskriptif kualitatif) yang bisa disebut penelitian kualitatif. Noor (2015 : 13) Data kualitatif merupakan bentuk data bukan bilangan, atau data yang disampaikan berbentuk kata-kata atau berbentuk kategori. Susanto dalam Edison dkk. (2016 : 17) Analisis SWOT (S) Strengths, (W) Weakness, (O) Opportunities, and (T) Threats 
adalah alat yang penting untuk perumusan strategi. Asumsi utama yang pokok adalah bahwa perusahaan harus menyelaraskan kegiatan di dalamnya dengan realitas eksternal untuk dapat mencapai target yang ditentukan.

1. Faktor Internal

a. Strengths ialah faktor di dalam lingkup organisasi dan merupakan kelebihan organisasi.

b. Weakness ialah faktor di dalam oganisasi yang dapat memperlambat pertumbuhan dan keberhasilan organisasi.

\section{Faktor Eksternal}

a. Opportunities adalah faktor yang ada di luar dari organisasi yang dimanfaatkan untuk membantu mengembangkan bisnis, seperti pasar yang luas.

b. Threats adalah faktor yang di luar daripada organisasi, seperti kekuatan pesaing yang bisa mengancam pertumbuhan organisasi.

Setelah menentukan faktor-faktor dalam SWOT, langkah pertama tentukan bobot, rating, dan score. Penilaian bobot di dasarkan pada tingkat kepentingan/urgensi penanganan dari skala (1) tidak penting, sampai (4) sangat penting.

Kedua, jumlahkan bobot (kekuatan dan kelemahan). Selanjutnya, hitung (bobot relatif) pada masing-masing faktor kekuatan dan kelemahan, agar total nilai bobot menjadi 1 atau menjadi $100 \%$. Cara yang sama untuk menghitung (bobot dan bobot relatif) pada faktor peluang dan faktor ancaman.

Ketiga, tentukan rating untuk menganalisis kemungkinan yang dapat terjadi pada tahun berikutnya. Nilai rating Variabel Kekuatan (nilai 1 - 4). Nilai 1 apabila pada indikator kinerjanya sangat menurun daripada lawan utama. Nilai 2, indikator tersebut yang kinerjanya sama dibanding pesaing utama. Sedangkan nilai 3 dan 4, kalau indikatornya lebih baik (unggul) daripada lawan utama. Makin tinggi suatu nilai kinerja indikator itu maka tahun berikutnya akan menjadi semakin baik daripada pesaing utama.

Nilai rating Variabel Kelemahan (nilai 1 -4). Nilai 1 apabila pada indikator itu semakin banyak kekurangannya (kelemahannya) daripada lawan utama. Sebaliknya, apabila nilai 4 berarti kelemahan pada indikator tersebut akan menjadi semakin menurun daripada pesaing utama di tahun berikutnya. Pemberian suatu nilai rating pada variabel kelemahan dan ancaman berkebalikan pada pemberian untuk nilai rating variabel kekuatan serta variabel peluang.

Nilai Score akan di dapat berdasarkan pada hasil dari nilai bobot dikalikan dengan nilai rating. Total nilai score pada internal factor apabila nilainya mendekati 1 , akan semakin banyak pula kelemahan pada internal daripada kekuatannya. Sedangkan apabila nilai internalnya mendekati 4, berarti semakin besar kekuatannya daripada kelemahannya.

Begitu juga pada total nilai score kepada faktor eksternal. Semakin total nilai mendekati 1 , berarti semakin banyak pula ancamannya daripada peluang. Sedangkan jika jumlah nilai score mendekati 4, berarti makin besar memiliki peluang daripada ancaman.

Kombinasi dari kedua kondisi internal maupun eksternal, seterusnya di masukkan ke Internal External Matrix, agar dapat mengetahui letak persaingan pada perusahaan, unit bisnis, ataupun produk yang diteliti. Berdasarkan posisi ini, penentuan strategi yang pas dapat memenangkan suatu persaingan di tahun depan.

\section{Hasil Penelitian dan Pembahasan}

Strategi pomosi pada Dodol Produksi Ibu Mita Kandangan dalam strategi promosi selama ini hanya menjual produknya secara tatap muka (Personal Selling) ke toko-toko di sekitar Kota kandangan dan kota lain. 
Peneliti menemukan bahwa Dodol produksi Ibu Mita Kandangan memang memerlukan langkah perbaikan untuk strategi promosi yang dapat meningkatkan penjualan Dodol Produksi Ibu Mita Kandangan dengan memilih strategi promosi yang tepat untuk meningkatkan penjualan produk.

Guna memperbaiki strategi promosi Dodol Produksi Ibu Mita Kandangan antara lain sebagai berikut:

1. Periklanan

Periklanan adalah sesuatu bentuk promosi dalam gagasan atau penyajian dalam bentuk jasa atau barang yang ditanggung sebuah sponsor bersifat non personal. Periklanan seperti majalah, televisi, radio, papan iklan dan surat kabar. Periklanan yang seharusnya dilakukan oleh Dodol Produksi Ibu Mita Kandangan untuk meningkatkan penjualan dengan cara memasang iklan produk lewat radio, papan iklan dan surat kabar.

2. Promosi penjualan

Promosi penjualan yang termasuk kegiatan dari personal selling, advertensi, dan publisitas yang memicu pembelian untuk konsumen seperti pameran dagang. Promosi penjualan yang seharusnya dilakukan Dodol Produksi Ibu Mita Kandangan untuk meningkatkan penjualan dengan cara memberikan diskon kepada pelanggan.

\section{Public relations}

Public relations ialah usaha untuk memicu permintaan dari suatu produk nonpersonal dengan membuat, baik yang berupa berita yang bersifat komersial tentang produk tersebut di dalam media tercetak atau tidak, maupun hasil wawancara yang disiarkan dalam media tersebut. Public relations yang seharusnya dilakukan Dodol Produksi Ibu Mita Kandangan untuk meningkatkan penjualan dengan melakukan kegiatan sosial dan acara yang melibatkan masyarakat secara langsung, membuat penawaran iklan, tatap muka, menawarkan produk dan bernegosiasi langsung dengan konsumen.

\section{Personal selling}

Personal selling adalah secara lisan penyajiannya seperti berbicara kepada seseorang atau beberapa calon konsumen tujuannya agar penjualan terealisasi. Personal selling sudah dijalankan secara efektif dengan cara konsumen menyampaikan informasi kepada konsumen yang lain mengenai produk tersebut.

\section{Direct \& Online marketing}

Penggunaan surat, telepon, fax, email atau Internet untuk berkomunikasi secara langsung kepada pelanggan atau untuk mendapatkan respon langsung dari konsumen atau calon pembeli. Direct \& online marketing yang perlu diterapkan Dodol Produksi Ibu Mita Kandangan yaitu dengan mempromosikan produk lewat media sosial seperti Instagram, Facebook Twitter, WhatsApp dan media lainnya.

Hasil analisis internal dan eksternal sebagai hal yang menetukan kekuatan, kelemahan, peluang dan ancaman yang dihadapi perusahaan.

1. Matriks Faktor Strategi Eksternal

Berikut ini langkah-langkah dalam menentukan Faktor Strategi Eksternal:

a. Setelah menentukan faktor-faktor dalam SWOT, langkah pertama tentukan bobot, rating, dan score. Penilaian bobot di dasarkan pada tingkat kepentingan/urgensi penanganan dari skala (1) tidak penting, sampai (4) sangat penting. 
b. Kedua, jumlahkan bobot (peluang dan ancaman). Selanjutnya, hitung (bobot relatif) pada masing-masing faktor peluang dan ancaman dengan cara nilai rata-rata pada masingmasing indikator dibagi dengan total bobot, agar total nilai bobot menjadi 1 atau menjadi $100 \%$.

c. Ketiga, tentukan rating untuk menganalisis kemungkinan yang dapat terjadi pada tahun berikutnya. Nilai rating Variabel Peluang (nilai 1 - 4). Nilai 1 apabila pada indikator kinerjanya sangat menurun daripada lawan utama. Nilai 2, indikator tersebut yang kinerjanya sama dibanding pesaing utama. Sedangkan nilai 3 dan 4, kalau indikatornya lebih baik (unggul) daripada lawan utama. Makin tinggi suatu nilai kinerja indikator itu maka tahun berikutnya akan menjadi semakin baik daripada pesaing utama. Nilai rating Variabel Ancaman (nilai $1-4$ ). Nilai 1 apabila pada indikator itu semakin banyak ancamannya daripada lawan utama. Sebaliknya, apabila nilai 4 berarti kelemahan pada indikator tersebut akan menjadi semakin menurun daripada pesaing utama di tahun berikutnya. Pemberian suatu nilai rating pada variabel peluang berkebalikan pada pemberian untuk nilai rating variabel ancaman.

d. Nilai Score akan di dapat berdasarkan pada hasil dari nilai bobot dikalikan dengan nilai rating. Total nilai score pada external factor apabila nilainya mendekati 1, akan semakin banyak pula ancaman pada eksternal daripada peluangnya. Sedangkan apabila nilai eksternalnya mendekati 4 , berarti semakin besar peluang daripada ancamannya.

Matrik EFAS (Eksternal Strategic Factors Analysis Summary) tentang faktor strategi eksternal, dapat dilihat pada tabel 4.

Tabel 4. Perhitungan EFAS PELUANG:

FAKTOR-FAKTOR STRATEGI EKSTERNAL

BOBOTRELATIF RATING SKOR

\begin{tabular}{|c|c|c|c|c|}
\hline $\begin{array}{l}\text { - Periklanan, mempromosikan iklan produk lewat radio, papan } \\
\text { iklan dan surat kabar secara maksimal. }\end{array}$ & 3,3 & 0,131 & 3,3 & 0,432 \\
\hline $\begin{array}{l}\text { - Promosi Penjualan, mengikuti pameran dagang demonstrasi } \\
\text { memberikan diskon secara maksimal. }\end{array}$ & 3,3 & 0,131 & 3,3 & 0,432 \\
\hline $\begin{array}{l}\text { - Public Relations, mempromosikan produk lewat acara (events) } \\
\text { secara maksimal. }\end{array}$ & 3,6 & 0,143 & 3,6 & 0,514 \\
\hline $\begin{array}{l}\text { - Personal Selling, memaksimalkan negoisasi produk kepada } \\
\text { konsumen. }\end{array}$ & 3,6 & 0,143 & 3,6 & 0,514 \\
\hline $\begin{array}{l}\text { - Direct \& Online, memaksimalkan promosi lewat surat, telepon } \\
\text { dan internet. }\end{array}$ & 3,3 & 0,131 & 3,3 & 0,432 \\
\hline TOTAL & 17,1 & 0,68 & & 2,324 \\
\hline ANCAMAN: & BOBOT & RELATIF & RATING & SKOR \\
\hline $\begin{array}{l}\text { - Periklanan, usaha industri lain telah menerapkan iklan seperti } \\
\text { radio, papan iklan dan surat kabar secara maksimal. }\end{array}$ & 1,7 & 0,067 & 1,7 & 0,113 \\
\hline $\begin{array}{l}\text { Promosi Penjualan, usaha industri lain sering mengikuti } \\
\text { berbagai pameran, demonstrasi dan memberikan diskon secara } \\
\text { maksimal. }\end{array}$ & 1,7 & 0,067 & 1,7 & 0,113 \\
\hline $\begin{array}{l}\text { Public Relations, usaha industri lain sudah mempromosikan } \\
\text { produk seperti acara (events) secara maksimal. }\end{array}$ & 1,7 & 0,067 & 1,7 & 0,113 \\
\hline $\begin{array}{l}\text { - Personal Selling, usaha industri lain sudah memaksimalkan } \\
\text { negoisasi penjualan. }\end{array}$ & 1,3 & 0,052 & 1,3 & 0,067 \\
\hline $\begin{array}{l}\text { - Direct \& Online, usaha industri lain sudah mempromosikan } \\
\text { lewat surat, telepon dan internet secara maksimal. }\end{array}$ & 1,7 & 0,067 & 1,7 & 0,113 \\
\hline TOTAL & 8,1 & 0,32 & & 0,519 \\
\hline TOTAL & 25,2 & 1,00 & & $\mathbf{2 , 8 4 3}$ \\
\hline
\end{tabular}


Ukuran Pembobot :

Angka 1 = Sedikit Penting

Angka 2 = Agak Penting

Angka 3 = Penting

Angka 4 = Sangat Penting

(Freddy Rangkuti, $2016: 31$ )

\section{Ukuran Rating:}

Angka 1 = Sedikit Kuat

Angka 2 = Agak Kuat

Angka 3 = Kuat

Angka 4 = Sangat Kuat

Berdasarkan tabel 4 mengenai hasil perhitungan EFAS dapat disimpulkan bahwa peluang terbesar adalah dari public relations dan personal selling yang menunjukkan nilai skor sebesar 0,514 , artinya dari peluang public relations dan personal selling UD. Dodol Produksi Ibu Mita perlu menerapkan personal selling dengan cara memaksimalkan negoisasi produk kepada konsumen dan public relations mempromosikan produk lewat acara (events) secara maksimal. Sedangkan ancaman terbesar adalah dari periklanan, promosi penjualan, public relations, dan direct \& online yang menunjukkan nilai skor 0,113 , artinya dari ancaman periklanan, promosi penjualan, public relations, dan direct \& online UD. Dodol Produksi Ibu Mita perlu menerapkan periklanan seperti radio, papan iklan dan surat kabar secara maksimal, promosi penjualan mengikuti berbagai pameran secara maksimal, public relations mempromosikan produk lewat acara dan direct \& online mempromosikan lewat surat, telepon dan internet secara maksimal. Hasil dari matriks EFAS adalah 2,843 hal ini berarti respon UD. Dodol Produksi Ibu Mita Kandangan dalam memanfaatkan peluang untuk mengatasi ancaman sudah diatas rata-rata.

\section{Tabel 5. Komentar EFAS}

\section{FAKTOR-FAKTOR STRATEGI EKSTERNAL} PELUANG:

- Periklanan, mempromosikan iklan produk lewat radio, dan surat kabar secara maksimal.

- Promosi Penjualan, mengikuti pameran dagang demonstrasi memberikan diskon secara maksimal.

- Public Relations, mempromosikan produk lewat acara (events) secara maksimal.

- Personal Selling, memaksimalkan negoisasi produk kepada konsumen.

- Direct \& Online, memaksimalkan promosi lewat surat, telepon dan internet.

\begin{tabular}{lll}
\hline ANCAMAN: & \multicolumn{1}{c}{ KOMENTAR } \\
\hline - & $\begin{array}{l}\text { Periklanan, usaha industri lain telah menerapkan } \\
\text { iklan seperti radio, papan iklan dan surat kabar } \\
\text { secara maksimal. }\end{array}$ & $\begin{array}{l}\text { Mengembangkan iklan seperti surat kabar atau } \\
\text { radio }\end{array}$ \\
\hline - & $\begin{array}{l}\text { Promosi Penjualan, usaha industri lain sering } \\
\text { mengikuti berbagai pameran, demonstrasi dan } \\
\text { memberikan diskon secara maksimal. }\end{array}$ & $\begin{array}{l}\text { Mengikuti berbagai acara atau diskon ke } \\
\text { pelanggan }\end{array}$ \\
\hline - & $\begin{array}{l}\text { Public Relations, usaha industri lain sudah } \\
\text { mempromosikan produk seperti acara (events) } \\
\text { secara maksimal. }\end{array}$ & $\begin{array}{l}\text { Mengadakan kegiatan sosial yang melibatkan } \\
\text { masyarakatnya secara langsung }\end{array}$ \\
\hline - & $\begin{array}{l}\text { Personal Selling, usaha industri lain sudah } \\
\text { memaksimalkan negoisasi penjualan. }\end{array}$ & Bernegoisasi langsung dengan konsumen \\
\hline - $\quad \begin{array}{l}\text { Direct \& } \text { Online, usaha industri lain sudah } \\
\text { mempromosikan lewat surat, telepon dan internet } \\
\text { secara maksimal. }\end{array}$ & $\begin{array}{l}\text { Mengembangkan lewat media sosial seperti } \\
\text { Instagram, WhatsApp dan media lainnya. }\end{array}$ \\
\hline
\end{tabular}

\section{KOMENTAR}

Untuk memberi tahukan kepada masyarakat luas khususnya daerah sendiri dan umumnya antar daerah

Menyesuaikan variasi penawaran dan permintaaan jangka pendek

Mendukung citra perusahaan

Dapat mengetahui reaksi pelanggan secara langsung

Menjangkau target pasar

Mengembangkan iklan seperti surat kabar atau 
Peluang yang dapat dimanfaatkan Dodol Produksi Ibu Mita untuk mengatasi ancaman adalah:

a. Mempromosikan iklan produk lewat radio, papan iklan dan surat kabar secara maksimal.

b. Mengikuti pameran dagang demonstrasi memberikan diskon secara maksimal.

c. Mempromosikan produk lewat acara (events) secara maksimal.

d. Memaksimalkan negoisasi produk kepada konsumen.

e. Memaksimalkan promosi lewat surat, telepon dan internet.

2. Matriks Faktor Strategi Internal

a. Setelah menentukan faktor-faktor dalam SWOT, langkah pertama tentukan bobot, rating, dan score. Penilaian bobot di dasarkan pada tingkat kepentingan/urgensi penanganan dari skala (1) tidak penting, sampai (4) sangat penting.

b. Kedua, jumlahkan bobot (kekuatan dan kelemahan). Selanjutnya, hitung (bobot relatif) pada masing-masing faktor kekuatan dan kelemahan dengan cara nilai rata-rata pada masing-masing indikator dibagi dengan total bobot, agar total nilai bobot menjadi 1 atau menjadi $100 \%$.

c. Ketiga, tentukan rating untuk menganalisis kemungkinan yang dapat terjadi pada tahun berikutnya. Nilai rating Variabel Kekuatan (nilai 1 - 4). Nilai 1 apabila pada indikator kinerjanya sangat menurun daripada lawan utama. Nilai 2, indikator tersebut yang kinerjanya sama dibanding pesaing utama. Sedangkan nilai 3 dan 4, kalau indikatornya lebih baik (unggul) daripada lawan utama. Makin tinggi suatu nilai kinerja indikator itu maka tahun berikutnya akan menjadi semakin baik daripada pesaing utama. Nilai rating Variabel Kelemahan (nilai 1 - 4). Nilai 1 apabila pada indikator itu semakin banyak kekurangannya (kelemahannya) daripada lawan utama. Sebaliknya, apabila nilai 4 berarti kelemahan pada indikator tersebut akan menjadi semakin menurun daripada pesaing utama di tahun berikutnya. Pemberian suatu nilai rating pada variabel kelemahan berkebalikan pada pemberian untuk nilai rating variabel kekuatan.

d. Nilai Score akan di dapat berdasarkan pada hasil dari nilai bobot dikalikan dengan nilai rating. Total nilai score pada internal factor apabila nilainya mendekati 1 , akan semakin banyak pula kelemahan pada internal daripada kekuatannya. Sedangkan apabila nilai internalnya mendekati 4 , berarti semakin besar kekuatannya daripada kelemahannya.

Matrik IFAS (Internal Strategic Factors Analysis Summary) tentang faktor strategi internal, dapat dilihat pada tabel 6 .

\section{Ukuran Pembobot :}

Angka $1=$ Sedikit Penting

Angka $2=$ Agak Penting

Angka $3=$ Penting

Angka $4=$ Sangat Penting

(Freddy Rangkuti, $2016: 31$ )

\author{
Ukuran Rating: \\ Angka $1=$ Sedikit Kuat \\ Angka 2 = Agak Kuat \\ Angka 3 = Kuat \\ Angka 4 = Sangat Kuat
}

Berdasarkan tabel 6 mengenai hasil perhitungan IFAS dapat disimpulkan bahwa kekuatan terbesar adalah dari personal selling yang menunjukkan nilai skor sebesar 0,525, artinya dari kekuatan personal selling UD. Dodol Produksi Ibu Mita menerapkan personal selling dengan cara memaksimalkan negoisasi produk kepada konsumen. Sedangkan kelemahan terbesar adalah dari periklanan, promosi penjualan, public relations, dan direct \& online yang menunjukkan nilai skor 0,117 , artinya dari kelemahan periklanan, promosi penjualan, 
public relations, dan direct \& online UD. Dodol Produksi Ibu Mita perlu menerapkan periklanan seperti radio, papan iklan dan surat kabar secara maksimal, promosi penjualan mengikuti berbagai pameran secara maksimal, public relations mempromosikan produk lewat acara dan direct \& online mempromosikan lewat surat, telepon dan internet secara maksimal. Hasil dari matriks IFAS adalah 2,765 hal ini menunjukkan UD. Dodol Produksi Ibu Mita Kandangan dalam menggunakan kekuatan untuk mengantisipasi kelemahan relatif sedang atau diatas rata-rata.

Tabel 6. Perhitungan IFAS

FAKTOR-FAKTOR STRATEGI INTERNAL BOBOT RELATIF RATING SKOR
KEKUATAN:

$\begin{array}{llllll}\text { - } & \text { Periklanan, mengiklankan produk lewat radio, } & 3,3 & 0,134 & 3,3 & 0,442\end{array}$ papan iklan dan surat kabar.

$\begin{array}{lllll}\text { - Promosi Penjualan, mengikuti pameran } & 3,3 & 0,134 & 3,3 & 0,442\end{array}$ dagang demonstrasi dan memberikan diskon.

$\begin{array}{lllll}\text { - Public Relations, mempromosikan produk } & 3,3 & 0,134 & 3,3 & 0,442\end{array}$ lewat acara (events).

$\begin{array}{lllll}\text { - Personal Selling, menegoisasikan penjualan } & 3,6 & 0,146 & 3,6 & 0,525\end{array}$ produk kepada konsumen.

$\begin{array}{lllll}\text { - Direct \& Online, mempromosikan lewat surat, } & 3,3 & 0,134 & 3,3 & 0,442\end{array}$ telepon dan internet.

\begin{tabular}{|c|c|c|c|c|}
\hline TOTAL & 16,8 & 0,68 & & 2,293 \\
\hline KELEMAHAN: & BOBOT & RELATIF & RATING & SKOR \\
\hline $\begin{array}{l}\text { Periklanan, mempromosikan lewat radio, } \\
\text { papan iklan dan surat kabar belum maksimal. }\end{array}$ & 1,7 & 0,069 & 1,7 & 0,117 \\
\hline $\begin{array}{l}\text { Promosi Penjualan, mengikuti pameran } \\
\text { dagang, demonstrasi dan memberikan diskon } \\
\text { masih belum maksimal. }\end{array}$ & 1,7 & 0,069 & 1,7 & 0,117 \\
\hline $\begin{array}{l}\text { Public Relations, mempromosikan produk } \\
\text { lewat acara (events) masih kurang maksimal. }\end{array}$ & 1,7 & 0,069 & 1,7 & 0,117 \\
\hline $\begin{array}{l}\text { - Personal Selling, negoisasi penjualan yang } \\
\text { dilakukan kurang maksimal. }\end{array}$ & 1,1 & 0,045 & 1,1 & 0,004 \\
\hline $\begin{array}{l}\text { - Direct \& Online, promosi yang dilakukan } \\
\text { lewat surat, telepon dan internet kurang } \\
\text { maksimal. }\end{array}$ & 1,7 & 0,069 & 1,7 & 0,117 \\
\hline TOTAL & 7,9 & 0,32 & & 0,472 \\
\hline TOTAL & 24,7 & 1,00 & & 2,765 \\
\hline
\end{tabular}

Kekuatan yang dapat dimanfaatkan Dodol Produksi Ibu Mita untuk mengatasi kelemahan adalah:

1. Mengiklankan produk lewat radio, papan iklan dan surat kabar.

2. Mengikuti pameran dagang demonstrasi dan memberikan diskon.

3. Mempromosikan produk lewat acara (events).

4. Menegoisasikan produk kepada konsumen.

5. Mempromosikan lewat surat, telepon dan internet. 
Tabel 7. Komentar IFAS

\begin{tabular}{|c|c|}
\hline FAKTOR-FAKTOR STRATEGI INTERNAL & KOMENTAR \\
\hline KEKUATAN: & \\
\hline $\begin{array}{l}\text { - Periklanan, mengiklankan produk lewat radio, papan } \\
\text { iklan dan surat kabar. }\end{array}$ & Memiliki papan iklan di daerah \\
\hline $\begin{array}{l}\text { - Promosi Penjualan, mengikuti pameran dagang } \\
\text { demonstrasi dan memberikan diskon. }\end{array}$ & Menawarkan insentif \\
\hline $\begin{array}{l}\text { - Public Relations, mempromosikan produk lewat acara } \\
\text { (events). }\end{array}$ & $\begin{array}{l}\text { Menjangkau masyarakat lokal atau kelompok } \\
\text { tertentu }\end{array}$ \\
\hline $\begin{array}{l}\text { - Personal Selling, menegoisasikan penjualan produk } \\
\text { kepada konsumen. }\end{array}$ & Memiliki jaringan penjualan di setiap daerah \\
\hline $\begin{array}{l}\text { - Direct \& Online, mempromosikan lewat surat, telepon } \\
\text { dan internet. }\end{array}$ & $\begin{array}{l}\text { Meningkatkan hubungan dengan konsumen } \\
\text { yang sudah ada }\end{array}$ \\
\hline KELEMAHAN: & KOMENTAR \\
\hline $\begin{array}{l}\text { Periklanan, mempromosikan lewat radio, papan iklan } \\
\text { dan surat kabar belum maksimal. }\end{array}$ & Masih kurangnya dikenal secara luas \\
\hline $\begin{array}{l}\text { Promosi Penjualan, mengikuti pameran dagang, } \\
\text { demonstrasi dan memberikan diskon masih belum } \\
\text { maksimal. }\end{array}$ & Pembelian jangka pendek \\
\hline $\begin{array}{l}\text { - Public Relations, mempromosikan produk lewat acara } \\
\text { (events) masih kurang maksimal. }\end{array}$ & Batasan biaya \\
\hline $\begin{array}{l}\text { - Personal Selling, negoisasi penjualan yang dilakukan } \\
\text { kurang maksimal. }\end{array}$ & $\begin{array}{l}\text { Pesan tidak konsisten karena perbedaan } \\
\text { pengetahuan antar karyawan }\end{array}$ \\
\hline $\begin{array}{l}\text { Direct \& Online, promosi yang dilakukan lewat surat, } \\
\text { telepon dan internet kurang maksimal. }\end{array}$ & Tingkat respon umum rendah \\
\hline
\end{tabular}

\section{Kesimpulan} berikut:

Berdasarkan pada hasil penelitian ini, dapat diambil beberapa kesimpulan sebagai

1. Berdasarkan hasil dari matriks IFAS adalah 2,765 hal ini menunjukkan UD. Dodol Produksi Ibu Mita Kandangan dalam menggunakan kekuatan untuk mengantisipasi kelemahan relatif sedang atau diatas rata-rata.

2. Berdasarkan hasil dari matriks EFAS adalah 2,843 hal ini berarti respon UD. Dodol Produksi Ibu Mita Kandangan dalam memanfaatkan peluang untuk mengatasi ancaman sudah diatas rata-rata.

3. Walaupun secara eksternal sudah memanfaatkan peluang dan ancaman eksternal, organisasi perlu pembenahan secara internal, sehingga mampu menggunakan kekuatan yang dimiliki untuk memanfaatkan kesempatan yang ada.

Berdasarkan pada temuan-temuan yang didapat pada penelitian ini, dapat diambil beberapa saran sebagai berikut:

1. Berdasarkan hasil pembahasan, untuk mencapai tujuan Dodol Produksi Ibu Mita Kandangan perlu meningkatkan program periklanan seperti iklan produk melalui papan iklan, brosur, radio dan surat kabar.

2. Mengikuti pameran dagang demonstrasi memberikan diskon kepada konsumen.

3. Mempromosikan produk lewat acara (events), dengan melakukan kegiatan sosial dan acara yang melibatkan masyarakat secara langsung.

4. Berinteraksi langsung untuk mengetahui permasalahan konsumen dan keinginan konsumen, membuat penawaran iklan, tatap muka, dan bernegoisasi langsung dengan konsumen. 
5. Promosi menggunakan media sosial seperti: Instagram, Facebook, Twitter, WhatsApp dan media lainnya.

6. Dodol Produksi Ibu Mita Kandangan diharapkan dapat meningkatkan kegiatan promosi yang sudah dilaksanakan dengan memanfaatkan sarana pemasaran yang sudah ada.

7. Berusaha mencari segmen pasar yang baru dan menggunakan strategi pemasaran yang tepat atau disesuaikan dengan kondisi pasar.

8. Promosi yang selama ini sudah dilakukan, seperti personal selling dan periklanan perlu dipertahankan dan ditingkatkan, baik secara kualitas, maupun secara kuantitas. Dengan begitu diharapkan kedepannya dapat memaksimalkan bauran promosi yang sudah diterapkan.

\section{DAFTAR PUSTAKA}

Assauri, Sofjan. 2017. Manajemen Pemasaran. Edisi. 1 Cetakan ke-15. Jakarta: Rajawali Pers. Daryanto, 2013. Sari Kuliah Manajemen Pemasaran. Cetakan ke-2 (revisi). Bandung: Satu Nusa.

Edison, Emron dkk. 2017. Manajemen Sumber Daya Manusia. Cetakan Kedua. Bandung: Alfabeta.

Haryono. Strategi Pemasaran Produk Garam Untuk Meningkatkan Volume Penjualan. Jurnal. Probolinggo: Universitas Panca Marga. https://www.google.co.id (Diakses tanggal 04 April 2018)

Nofiar. Analisis Strategi Pemasaran Untuk Meningkatkan Volume Penjualan Produk Perusahaan Studi Kasus Pada PT. Global Haditech. Jurnal. FE Universitas Pamulang. https://www.google.co.id (Diakses tanggal 04 April 2018)

Noor, Juliansyah. 2015. Analisis Data Penelitian Ekonomi \& Manajemen. Cetakan Kedua. Jakarta: PT. Garasindo.

Rangkuti, Freddy. 2016. Teknik Membedah Kasus Bisnis Analisis SWOT. Cetakan keduapuluh dua. Jakarta: PT. Gramedia.

Sugiyono. 2017. Statistika Untuk Penelitian. Cetakan Ke-28. Bandung: Alfabeta.

Suryabrata, Sumadi. 2014. Metodologi Penelitian. Edisi.2 Cetakan ke-25. Jakarta: Rajawali Pers.

Tjiptono, Fandy. 2015. Strategi Pemasaran Edisi - 4. Yogyakarta: ANDI.

Zevi, Irfan. 2018. Analisis Data Pemasaran Dalam Meningkatkan Volume Penjualan Produk Pada PT. Proderma Sukses Mandiri. Skripsi. Jakarta: UIN. https://www.google.co.id (Diakses tanggal 04 April 2018) 